\title{
Competency and Performance Gap between Executive and Non-Executive Employees of Banks in Kerala, India
}

\author{
Ramkumar T Balan
}

\begin{abstract}
This paper assesses the Competency and Performance of bank employees of Four banks in Kerala, India. The gap in the performance and competency of executive and non- executive employees of the banks were determined. The linear regression model is estimated on dimensions of this efficiency measures. Also logistic regression models on competency and performance for executive and non-executive employees were identified. The dimensions of effectiveness of employees in a banking work place on both groups were compared. The gap in the characteristics of two sets of employees is illustrated for various demographic groups.
\end{abstract}

Index Terms - Competency, Performance, Executives, Non-Executives, Skills, Linear regression, logistic model.

\section{INTRODUCTION}

"Competency is an underlying characteristic of an individual that is causally related to effective and/or superior performance in a job or a situation." (Boyatzis, 1982). Competency is the sum total of all skills, knowledge and attitudes, manifested in the employee's behaviour. Employees with high competency are really the resource of the institution to extend planning, development and organising service at appropriate time within a speedy deliverance. According to Cheng et.al (2003) "the establishment of the competency of individuals is crucial for the further development of an organization". Therefore, it is very essential to identify the individual competencies to improve the performance of the employees. The efficiency of many institutions like banks, universities, government offices, research centres etc were highly depends on individual competency of the persons involved in their respectable positions. According to Randy (2000), 40 to 80 percent of customer satisfaction and loyalty is determined by the customer-employee relationship depending upon the industry and market segment. Mangaleswaran T and Srinivasan P T (2007) designed an empirical study to explore and compare Human Resource Management practices in Sri Lankan and Indian Public Sector Banks. Human Resource Management (HRM) is a modern developed concept and it has tremendous relevance to service sector like Banks.

According to Kwabena Frimpong and Alan Wilson (2012) though a great deal of attention has been given to measuring service orientation as a personality trait, very little attention has been given to conceptualizing and measuring the

Ramkumar T Balan, Department of Statistics, College of Natural and Mathematical Sciences, University of Dodoma, Tanzania. construct in terms of what employees actually do in service delivery. The few studies that have attempted to fill this gap tend to focus narrowly on what service employees do in their interactions with external customers via global measures excelling competency.

Performance is a degree of achievability to predetermined business objectives. Performance is a result as well as quantitative and qualitative measurement of efforts to achieve the aim ((Chan, J. K. L., \& Baum, T. (2007); Jennifer Kim Lian Chan and Wei Boon Quah. (2012)). Another definition of the performance is that performance is "the quantitative and qualitative explanation of what things provided by a person, a group of people or an organization towards the intended target related to the work done" (Salem Al-Oun, 2012; Sinclair D and Zairi M. 1995). A service firm can determine whether or not it provides quality service only by making performance measurement regularly. Although, performance measurement in service firms is slightly harder and more complex than the one in manufacturing plants, it is a kind of operation that should be applied in them, too. (Modell, S. 2001; Ludeman K. 2000; Luft, J. 2004). Kadian W. Wanyama and S. N. Mutsotso (2015) conducted a study "Relationship between capacity building and employee productivity on performance of commercial banks in Kenya" focusing on the influence of employee productivity on organizational performance. This study investigated the impact of capacity building and employee productivity on commercial banks. Kenya has experienced banking problems since independence in 1964 culminating in major bank failures (37 failed banks as at 1998). The bank failures were largely due to weak supervision; poor service delivery, poor public relations and organizational ineffectiveness. Their study revealed that equipping employees with expertise, skills and knowledge can improve employee productivity and thereby improve performance of the banks.

In this way, the use of human resource should be made more productive. Major problem arising from the management of human resources is to employing less people in units in which more people are actually needed and employing many people in units in which just a few people are needed to perform the related tasks of the unit. Because of that, performance assessment will also help at these circumstances to determine beforehand the efficiency of employees and it should be applied surely.

To compete effectively, banking institutions need professionals with the ample skills and expertise at all functional areas. Thus, the banking sector gives more priority 
to strengthen their intellectual human resources and the competency of them. To build customer confidence and goodwill, driving customer satisfaction, enhancing reputation, and ultimately realising individual bank's corporate vision and strategic goals, competent staff had to deliver high quality products and services. Therefore, banking institutions are interested to ensure competency and professionalism to serve their customers better. Employees on the frontline in banking sector are in constant contact with the customer and the customer satisfaction depends upon employee performance that in turn depends on employee satisfaction. Thus competent, reliable and dedicated employees of banks are the assets on the performance of banks along with its policy and infrastructure. For understanding the needs of the customers and fulfilling them, the bank employees both at the managerial and clerical level must have the required level of competency in their behavioural and attitudinal skills.

Every person has different qualities, attitude, motives, personality traits, skills etc. that will affect their work performance. Human Resource (HR) department of banks is entrusted with the responsibility of searching, assigning and evaluating the employees by recruitment, selection and performance appraisal. The main objective of these functions is the assessment of suitability of the individuals for different functional jobs and developing their potential to be effective and excel in assigned jobs. This study aims to analyse, compare and contrast the gap of overall competency of executive and non-executive officers in commercial banks giving service in Kerala. This is done by analysing nine competent factors like knowledge, behaviour, leadership,risk management, personal and interpersonal skill etc possessed by an individual employee in both clerical and managerial levels and the means adopted to enhance their said skills in near future.

However, earlier studies show that, in banking sector, employees are less satisfied and less motivated than other lines of work employees (Kelley, 1990; Bajpai, Naval \& Deepak, 2004). This is reflected by high employee turnover rate (Branham, 2005; Nelson, 2007) and high level of stress (Chen \&Lien, 2008) in the banking industry. The overload of work, unnecessary change of working pattern, inadequate and untimely introduction of softwares, challenges of NPA collection, intervening of political and higher ups etc are creating distress among many of the employees of banks in India. The routine non-discretionary activities and monotonous his masters voice job systems and compulsions from higher quarters leads to reduce their competency even many are energetic and enthusiastic in the early years of service. The main goal of this article is to identify the way how the competencies are managed within banks and to evaluate the level of employee competencies in banks. The goal is built by detailed goals that refer to the presentation of competence management process in banks, the analysis of human capital management process and the evaluation of employee competencies development.

Kerala boasts of a well-developed banking infrastructure. With passage of time, Kerala banking system has attained a high benchmark. A large number of branches of nationalized and commercial banks along with Grameen banks have sprung up within the state. These banks play a vital role in the economic growth and overall development of the Kerala state. Along with financial capital and technology, human resources contribute a lot to the capabilities of the banking sector to face the new challenges thrown open by globalization and liberalization. It is in this context, the present study focuses on the management of the behavioural competencies of employees in the commercial banking sector servicing in Kerala.

Aim of Performance measurement is to increase the motivation of employees, provide on time and quick feedback, provide fairness in the structure of the organization, provide equal opportunities, support the employees and help them improve themselves (Griffith J. (2003); Key E. (2003). Performance is a continuously examined theme in most branches of management, including strategic management by both academic scholars and practicing managers. (Luft J. 2004).Performance measurement can be defined as "a method of measurement of how tasks are performed within a program impartially during the implementation of products, services, or processes"(Busco C., Ribacconi A. and Scapens R, 2006). The reasons of the performance measurement can be sequenced (written) like (are followings below) below:( Parker C, (2000; Kuen( 2000). SMART is a composite strategy to identify the competency and performance of employees.

S-specific: The aims should be related to the work done, agreed on, definite (concrete) and the workers should know what is expected from them. M-Measurable: The standards/aims should be objective and "measurable". It should determine how the success of the aim will be measured. If the standards are quantitative then the measurement is easier. However, if they are qualitative then it is necessary to be more careful. A-Achievable: Standards should be not only challenging but also reachable. Aims should not be very difficult that employees will never succeed and they should not be very easy as well to be able to achieve them. Relevant - Setting this type of goal lets you know what helps make you successful and what is ineffective. Increasing conversion rates also has numerous additional benefits to your business and your bottom line.Time-Bound - Your goal has a specific timeline in which you can implement changes and measure their success.

\section{METHODOLOGY}

Thus competency and performance of banks are highly correlated and one will substantiate other. So this study is widely deals with evaluation of competencies of employees of 4 banks and finding the gap in the competency between executive and non-executive employees. Around 200 clerks and 100 officers are selected randomly from Federal bank, South Indiabank, HDFC bank and Kotak Mahindra bank and investigation is conducted. Questionnaire is developed by 57 questions on nine designed factors and they are sequentially analysed with respect to age, sex, experience, etc. Using factor analysis the competency score and performance score were determined and they are further discriminated on banks and position of employees. Logistic regression model and multiple regression modelswere fitted to evaluate the 
objective variables. Cronbach's alpha and KMO test and Sphericity tests were applied to ensure the consistency and sample adequacy of factors. ANOVA is implemented to find the contrast between various groupings of employees on their competency and performance.Linear regression model of performance of executive and non- executive employees is determined with respect to five dimensions KS (Knowledge and Skill),CS (Communication Skill),LS (Leadership Skill) ,TS (Technical Skill), IS (Interpersonal Skill) and model on competency is found in terms of PC (Personal Competencies) , RMS ( Risk Management Skill) ,BC (Behavioural Competencies), POS (Planning and Objective Setting) . Also logistic model of competency and performance on demographic variables is designed and probability is estimated. Competency and performance gap between executive and non-executive employees is

Some basic demographic features

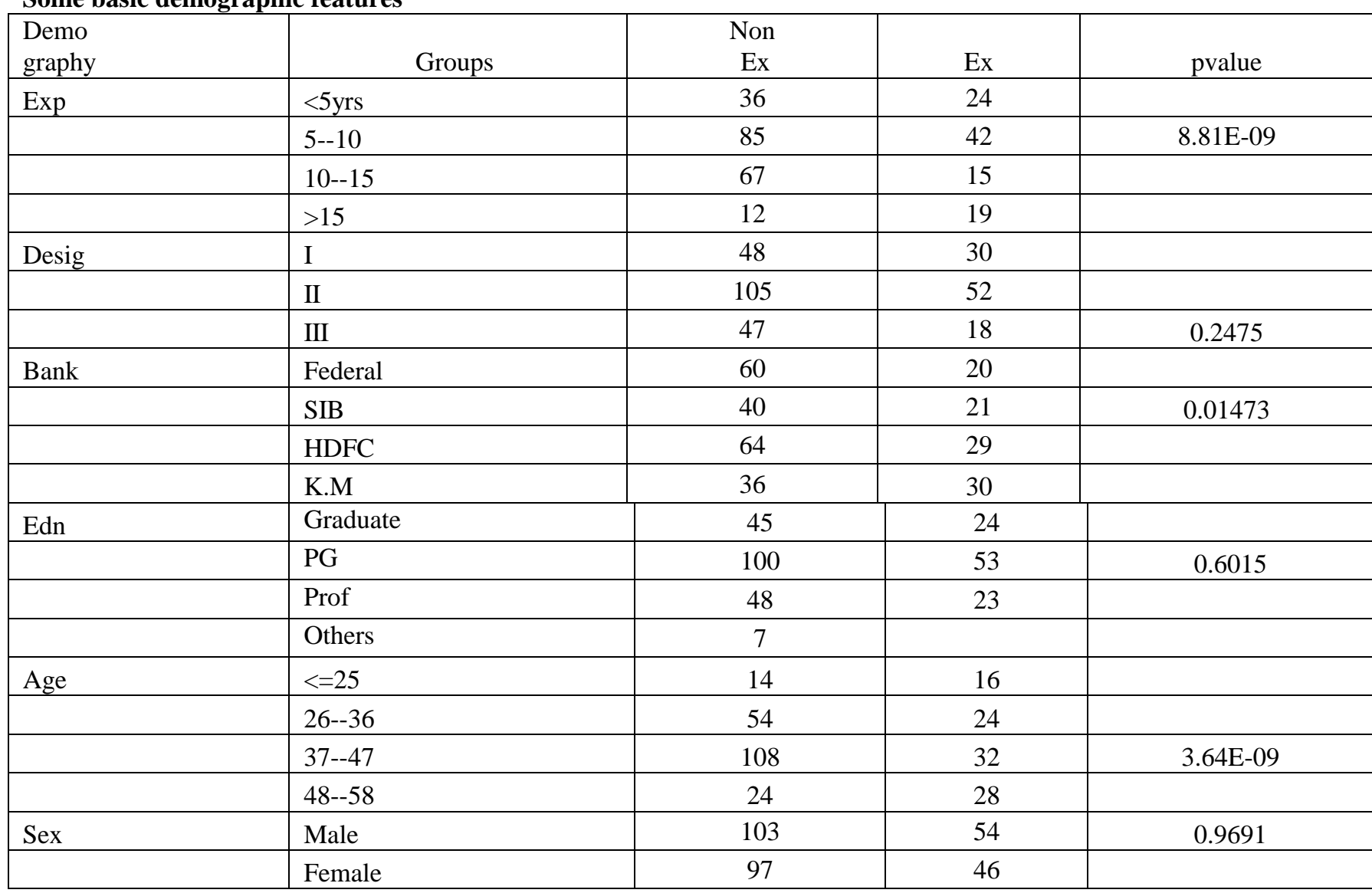

\section{Results}

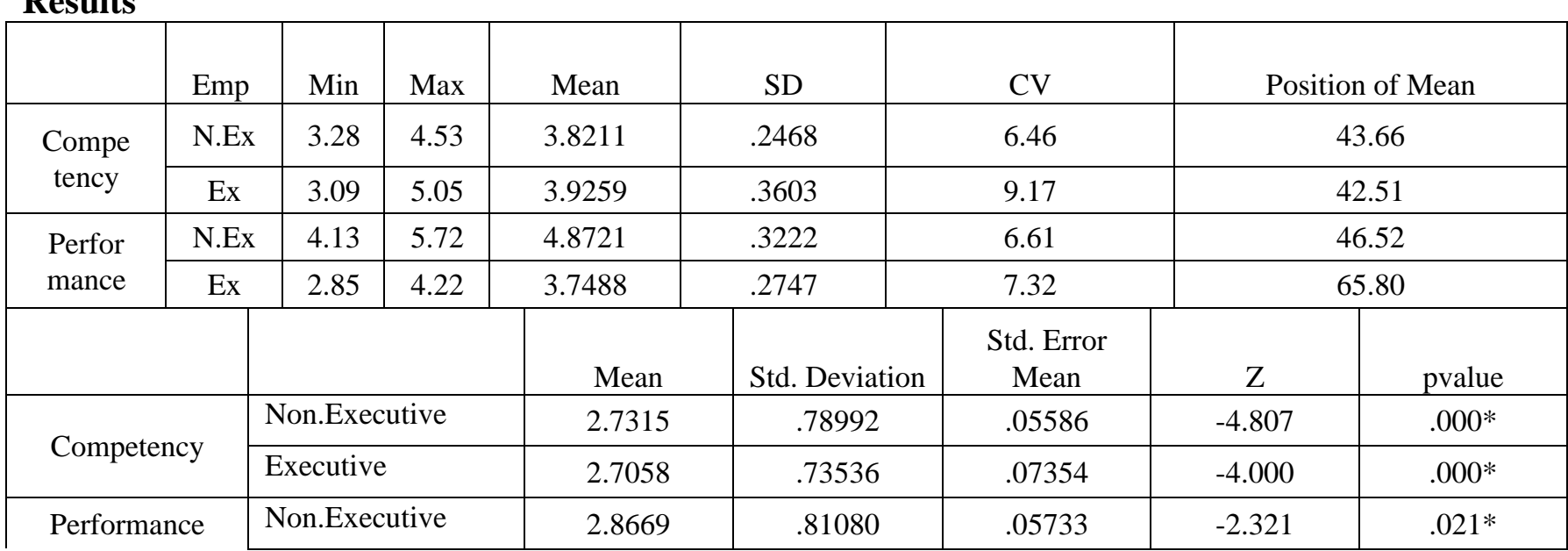

determined and estimated by graphic method. Gap significance is analysed and explored with respect to age, sex, experience, designation etc.

Age distribution of selected employees on executive and non-executive grades was not identical. But the sex, education ratios are equal. Experience of Ex and NEx employees in the data are significantly different. The representation ratio of Ex and NEx from different banks are also not identical.Competency and performance of non-executive employees is consistent compared to officers scores. (only $6.6 \%$ unit variation in performance and $6.5 \%$ in competency). The executive staff is $9 \%$ varying in competency and $7.3 \%$ in performance. All employee's competency grade is lacking middle point and it is significantly less from the neutral response. (pvalue $=0.000$,both $)$. 
.80218

.08022

7.781

$.000^{*}$

It is interesting to note that the averageperformance of executive staff is reasonably high in the transformed scale 1-5 showing that their opinion isagreeable. While the competency of employees is lacking the middle opinionimplying that average score on competency is not agreeable. The performance score of NEx is also lacking middle value.

The Gap between Ex and NEx staff is not identical.There is significant difference in the performance of Ex and NEx $(t=4.707$, pvalue $=0.000)$. Also there is significant difference in the competency of Ex and NEx $(t=11.036$, pvalue=0.000).
Comparison of competency and performance among demographic factors.

The following table show the $\mathrm{p}$ values of testing equality of competency and performance of both categoriesof employees with respect to the subdivisions of demographic factors.From the table there is significant difference in the competency and performance in different education levels, designation and the years of experience of clerical staff. The competency of clerks is different in different banks of non-executive staff but performance is identical among them.

\begin{tabular}{|l|c|c|c|c|}
\hline & \multicolumn{2}{|c|}{ Non*Executive-pvalue } & \multicolumn{2}{c|}{ Executive- pvalue } \\
\hline D. Variable & Competency & Performance & Competency & Performance \\
\hline Age & 0.086 & 0.083 & 0.183 & $0.012^{*}$ \\
\hline Gender & 0.371 & 0.302 & 0.429 & 0.781 \\
\hline Education & $0.048^{*}$ & $0.048^{*}$ & 0.510 & 0.091 \\
\hline Bank & $0.002^{*}$ & 0.076 & 0.609 & 0.794 \\
\hline Designation & $0.000^{*}$ & $0.000^{*}$ & 0.076 & 0.241 \\
\hline Experience & $0.000^{*}$ & $0.013^{*}$ & 0.285 & 0.200 \\
\hline
\end{tabular}

For the executive staff there is no significant difference between groups of demographic variables except in performance of different ages $(<=25$ years) of officers and managers. The performance and competence of male and female are alike on all categories of staff.Competency and performance of graduate, post graduate and other degrees is significantly different.There is considerable difference in the competency and performance of non-executive staff on various banks. Kotak Mahindra bank clerical staff performance is significantly different from Federal bank as $\mathrm{KMH}$ is private sector bank and Federal bank is scheduled bank. (0.017). In competency Federal

bank differs from South Indian bank and HDFC bank (0.001,0.009). Also SIB and HDFC clerical staff competency is different(0.010). Various designations in clerical category also show difference in performance and competency. Lower division clerk, senior clerk and cashiers are performing differently in both variables.(0.001,0.000,0.003, in performance and $0.001,0.000, \quad 0.008$ in competency).Experience wise also clerks differ in performance and competency. Below 5year clerical staff Comparison of performance and competency wrt demographic variable

\begin{tabular}{|c|c|c|c|c|c|c|}
\hline Age & $\begin{array}{c}\text { Performance } \\
\text { NE }\end{array}$ & $\begin{array}{c}\text { Competency } \\
\text { NE }\end{array}$ & $\begin{array}{c}\text { Performance } \\
\text { E }\end{array}$ & $\begin{array}{c}\text { Competence } \\
\text { E }\end{array}$ & $\begin{array}{c}\text { Performance } \\
\text { pvalue }\end{array}$ & $\begin{array}{c}\text { Competency } \\
\text { pvalue }\end{array}$ \\
\hline$<=25$ & 3.4149 & 3.0924 & 3.2738 & 1.5144 & 0.3690 & $0.0000^{*}$ \\
\hline $26--36$ & 3.1092 & 2.5635 & 3.3924 & 1.8550 & 0.0986 & $0.0000^{*}$ \\
\hline $37--47$ & 3.0392 & 2.7281 & 3.9530 & 1.8432 & $0.0000 *$ & $0.0000^{*}$ \\
\hline $48--58$ & 3.5026 & 2.9143 & 3.7163 & 1.7327 & 0.1905 & $0.0000^{*}$ \\
\hline Total & 3.1400 & 2.7315 & 3.6435 & 1.7625 & $0.0000 *$ & $0.0000^{*}$ \\
\hline
\end{tabular}

Between the performance score onthreeage group of Ex and NEx were identical and it is different for the age 37-47 in Ex and NEx. But competency at all age groups isentirely different. The competency and performance ofmale or is significantly different. excels differently with 5-10year experience in both cases $(0.000,0.007)$. Also significance is reported between $<5 \mathrm{yr}$ and $10-15$ year experience and 5---10 year with 10 -15years.( 0.000,0.009). 


\begin{tabular}{|l|c|c|c|c|c|c|}
\hline Sex & $\begin{array}{c}\text { Performance } \\
\text { NE }\end{array}$ & $\begin{array}{c}\text { Competency } \\
\text { NE }\end{array}$ & $\begin{array}{c}\text { Performance } \\
\text { E }\end{array}$ & $\begin{array}{c}\text { Competency } \\
\text { E }\end{array}$ & $\begin{array}{c}\text { Performance } \\
\text { pvalue }\end{array}$ & $\begin{array}{c}\text { Competency } \\
\text { pvalue }\end{array}$ \\
\hline Male & 3.0821 & 2.7668 & 3.6643 & 1.8022 & $9.32 \mathrm{E}-05^{*}$ & $0.000^{*}$ \\
\hline Female & 3.2223 & 2.6770 & 3.6190 & 1.7158 & $0.0037^{*}$ & $0.000^{*}$ \\
\hline Education & $\begin{array}{c}\text { Performance } \\
\text { NE }\end{array}$ & $\begin{array}{c}\text { Competency } \\
\text { NE }\end{array}$ & $\begin{array}{c}\text { Performance } \\
\text { E }\end{array}$ & $\begin{array}{c}\text { Competency } \\
\text { E }\end{array}$ & $\begin{array}{c}\text { Performance } \\
\text { pvalue }\end{array}$ & $\begin{array}{c}\text { Competency } \\
\text { pvalue }\end{array}$ \\
\hline Graduate & 3.1383 & 2.7692 & 3.8998 & 1.7838 & $0.00080^{*}$ & $0.0000^{*}$ \\
\hline PG & 3.1677 & 2.8293 & 3.6398 & 1.8026 & $0.00070^{*}$ & $0.0000^{*}$ \\
\hline Professional & 3.2193 & 2.5855 & 3.3847 & 1.6476 & 0.1640 & $0.0000^{*}$ \\
\hline Others & 2.2120 & 2.0938 & 3.6435 & 1.7625 & & \\
\hline
\end{tabular}

There is significant difference in performance and competency score of graduate and postgraduate employees of Ex and NEx categories. But for professionals in Ex and NEx performance is identical even though competency is different.

\begin{tabular}{|l|c|c|c|c|c|c|}
\hline Bank & $\begin{array}{c}\text { Performance } \\
\text { NE }\end{array}$ & $\begin{array}{c}\text { Competency } \\
\text { NE }\end{array}$ & $\begin{array}{c}\text { Performance } \\
\text { E }\end{array}$ & $\begin{array}{c}\text { Competency } \\
\text { E }\end{array}$ & $\begin{array}{c}\text { Performance } \\
\text { pvalue }\end{array}$ & $\begin{array}{c}\text { Competence } \\
\text { pvalue }\end{array}$ \\
\hline Federal & 3.3819 & 2.9628 & 3.6611 & 1.6877 & 0.0845 & $0.0000 *$ \\
\hline SIB & 3.0726 & 2.4179 & 3.6902 & 1.6945 & $0.0005 *$ & $0.0000 *$ \\
\hline HDFC & 3.0754 & 2.8209 & 3.4865 & 1.8611 & $0.0444 *$ & $0.0000 *$ \\
\hline KMB & 2.9265 & 2.5357 & 3.7068 & 1.8152 & $0.0001 *$ & $0.0000^{*}$ \\
\hline
\end{tabular}

In federal bank performance score are equal in Ex and NEx employees. But their competency is significantly different.For SIB,HDFC,KMB both are significantly different in Ex and NEx.

\begin{tabular}{|l|c|c|c|c|c|c|}
\hline Designation & $\begin{array}{c}\text { Performance } \\
\text { NE }\end{array}$ & $\begin{array}{c}\text { Competency } \\
\text { NE }\end{array}$ & $\begin{array}{c}\text { Performance } \\
\text { E }\end{array}$ & $\begin{array}{c}\text { Competency } \\
\text { E }\end{array}$ & $\begin{array}{c}\text { Performance } \\
\text { Pvalue }\end{array}$ & $\begin{array}{c}\text { Competency } \\
\text { pvalue }\end{array}$ \\
\hline I & 3.6255 & 3.1487 & 3.6101 & 1.7255 & 0.528342 & $0.000^{*}$ \\
\hline II & 3.1108 & 2.7006 & 3.7527 & 1.8628 & $7.58 \mathrm{E}-07^{*}$ & $0.000^{*}$ \\
\hline III & 2.6596 & 2.3397 & 3.3835 & 1.5341 & $0.000948^{*}$ & $0.000^{*}$ \\
\hline IV & 3.4412 & 2.8855 & 3.6435 & 1.7625 & & \\
\hline
\end{tabular}

In all different designations both characteristics of Ex and

NEx are significantly different.

\begin{tabular}{|l|c|c|c|c|c|c|}
\hline Experience & $\begin{array}{c}\text { Performance } \\
\text { NE }\end{array}$ & $\begin{array}{c}\text { Competency } \\
\text { NE }\end{array}$ & $\begin{array}{c}\text { Performance } \\
\text { E }\end{array}$ & $\begin{array}{c}\text { Competency } \\
\text { E }\end{array}$ & $\begin{array}{c}\text { Performance } \\
\text { pvalue }\end{array}$ & $\begin{array}{c}\text { Competency } \\
\text { pvalue }\end{array}$ \\
\hline$<5$ yrs & 3.6798 & 2.9636 & 3.4527 & 1.8933 & 0.8478 & $0.000 *$ \\
\hline $5-10$ & 2.9484 & 2.5413 & 3.7362 & 1.6715 & $1.9 \mathrm{E}-09 *$ & $0.000 *$ \\
\hline $10--15$ & 3.0371 & 2.8751 & 3.9216 & 1.8958 & $0.0012 *$ & $0.000 *$ \\
\hline$>15$ & 3.4530 & 2.5809 & 3.4601 & 1.6930 & 0.49092 & $0.000 *$ \\
\hline
\end{tabular}

Employees with experience of $<5$ years and $>15$ years does not show significant difference in their performance score but for other experience categories show difference of scores among Ex and NEx. Also competency score is different for various experience groups in Ex and NEx.

\section{Competency and Performance Gap}

Gap is defined as the difference in scores of Executive staff with Non-executive staff of same category. There are two gaps studied - competency gap and performance gap.Competency gap $=$ Score of Employees of
Exe-group-Score of employees of NEx group. If it is positive Ex competency is high and it is more if the positive value is more. If it is negative NEx competency is more and if negative magnitude is high then NEx competency is high. Competency can be composed of five components -Personal Competency (PC), Leadership Skill (LS), Risk Management Skill (RMS), Behavioural Competency (BC), Planning and Objective Setting (POS). From the figure the competency average is assessed in score of 4 to 5 in components. Competency is less in Nex on RMS and LS while it is less in POS and PC for Ex and same in BC. The area incurred by Ex and NEx polygon is almost identical. 


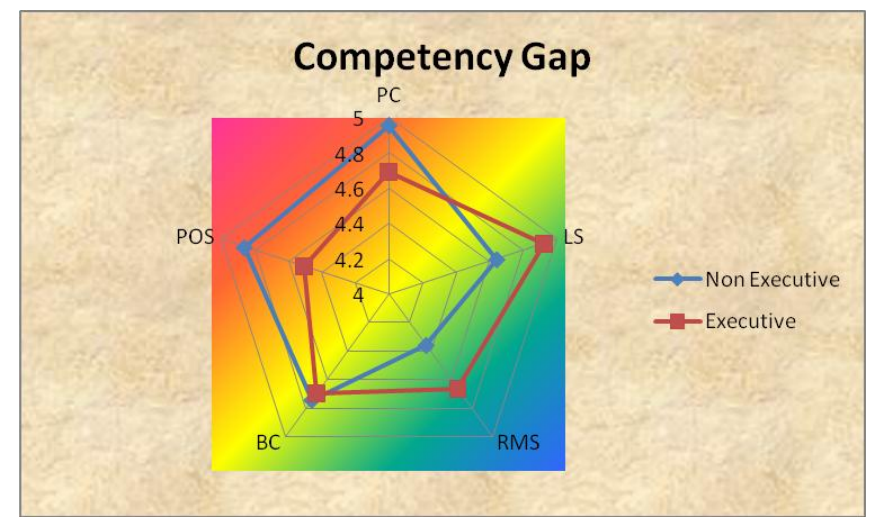

Performance Gap

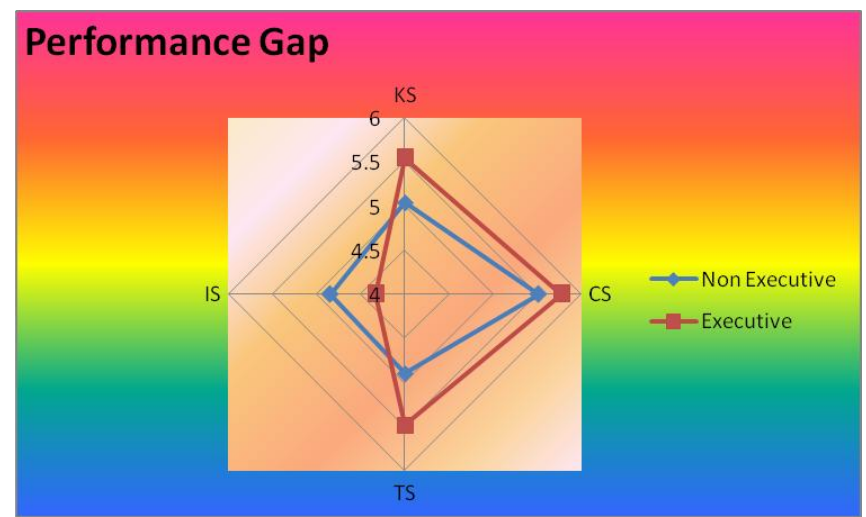

Performance can be composed of five components Performance model is developed on 4 components-Basic Knowledge and Skill (KS), Communication Skill (CS), Technical Skill (TS), Inter Personality Skill (IS). From the figure the Performance average is assessed in score of 4 to 6 in 4 components. Performance is less in non- executives on $\mathrm{CS}, \mathrm{KS}$ and TS while it is less in IS for executives. The area incurred by Ex is little high compared to NEx polygon implies the overall performance is more for executive staff.

Performance gap is positve except in <25years, while competency is negative in all ages. Highest gap of competency (Ex-NEx ) is at 37-47 years and in performance highest gap is in early ages and late ages. Competence and performance graph is given as to estimate the charactristics in any age between $25-58$. For example the competency gap at age 40 is 0.75 . Competency gap in male is less than in female but performance gap is more in male. The competency gap is almost equal in all the three categories and it is 1unit high for NEx. Performance gap is steadily decreasing from graduate to PG and PG to professional.Performance gap is high in Kotak Mahindra followed by SIB. Federal bank shows the minimum gap. Competency gap is very high in federal bank followed by HDFC. Thus these characteristics are in opposite direction in different banks. Performance is increasing for Ex staff for higher designation while competency is decreasing over designation

The competency of NEx is more and gap is 0.9 in 5-10 and more than 15 years. But it is high nearly 1 in the other experience group. Performance gap is negative in less than 5 year experience group and it is .8--.9 in anexperience of $5-15$ but it endure to .01 when experience exceeds 15 years.

\begin{tabular}{|c|c|c|c|c|c|c|c|}
\hline & & Performance & Competency & & & Performance & Competency \\
\hline \multirow[t]{4}{*}{ age } & $<=25$ & -0.14 & -1.58 & bank & Federal & 0.28 & -1.28 \\
\hline & $26-36$ & 0.28 & -0.71 & & SIB & 0.62 & -0.72 \\
\hline & $37-47$ & 0.91 & -0.88 & & HDFC & 0.41 & -0.96 \\
\hline & $48-58$ & 0.21 & -1.18 & & KMB & 0.78 & -0.72 \\
\hline \multirow[t]{2}{*}{$\operatorname{sex}$} & Male & 0.58 & -0.96 & \multirow{2}{*}{$\begin{array}{l}\text { desig } \\
\text { nation }\end{array}$} & $\mathrm{I}$ & -0.02 & -1.42 \\
\hline & Female & 0.42 & -0.98 & & II & 0.64 & -0.84 \\
\hline \multirow{4}{*}{$\begin{array}{l}\text { edu } \\
\text { cation }\end{array}$} & Graduate & 0.76 & -0.99 & & III & 0.72 & -0.81 \\
\hline & PG & 0.47 & -1.03 & \multirow{2}{*}{$\begin{array}{c}\text { exper } \\
\text { ience }\end{array}$} & $<5$ & -0.23 & -1.07 \\
\hline & Professional & 0.17 & -0.94 & & $5--10$ & 0.79 & -0.87 \\
\hline & & & & & $10--15$ & 0.88 & -0.98 \\
\hline Total & & 0.50 & -0.97 & & $>15$ & 0.01 & -0.89 \\
\hline
\end{tabular}


Performance is poor for executives in the early ages of service compared to ordinary staff but when they reach 25 or more their performance is getting sharper till 47 years and further declines till the end of retirement. In competency, clerks are more penchant and it is extreme at early ages. From the age of 26 the competency is width is widening between NEx and Ex-employees.Male average performance of Ex is more than Female Ex.Competency gap is high among post graduates while performance gap is high in graduate Ex. Kotak
Mahindra Ex staff performance gap is excellent compared to other banks. But competency of NEx of Federal bank is deplorable. Designation 1 employee's competency gap is very high and it is in designation 3 staff performance gap is high. Among employees within 5year experience. clerical staff performance and competency is upheld. No much difference in performance is found on officers compared to clerks when experience exceeds 16 years.

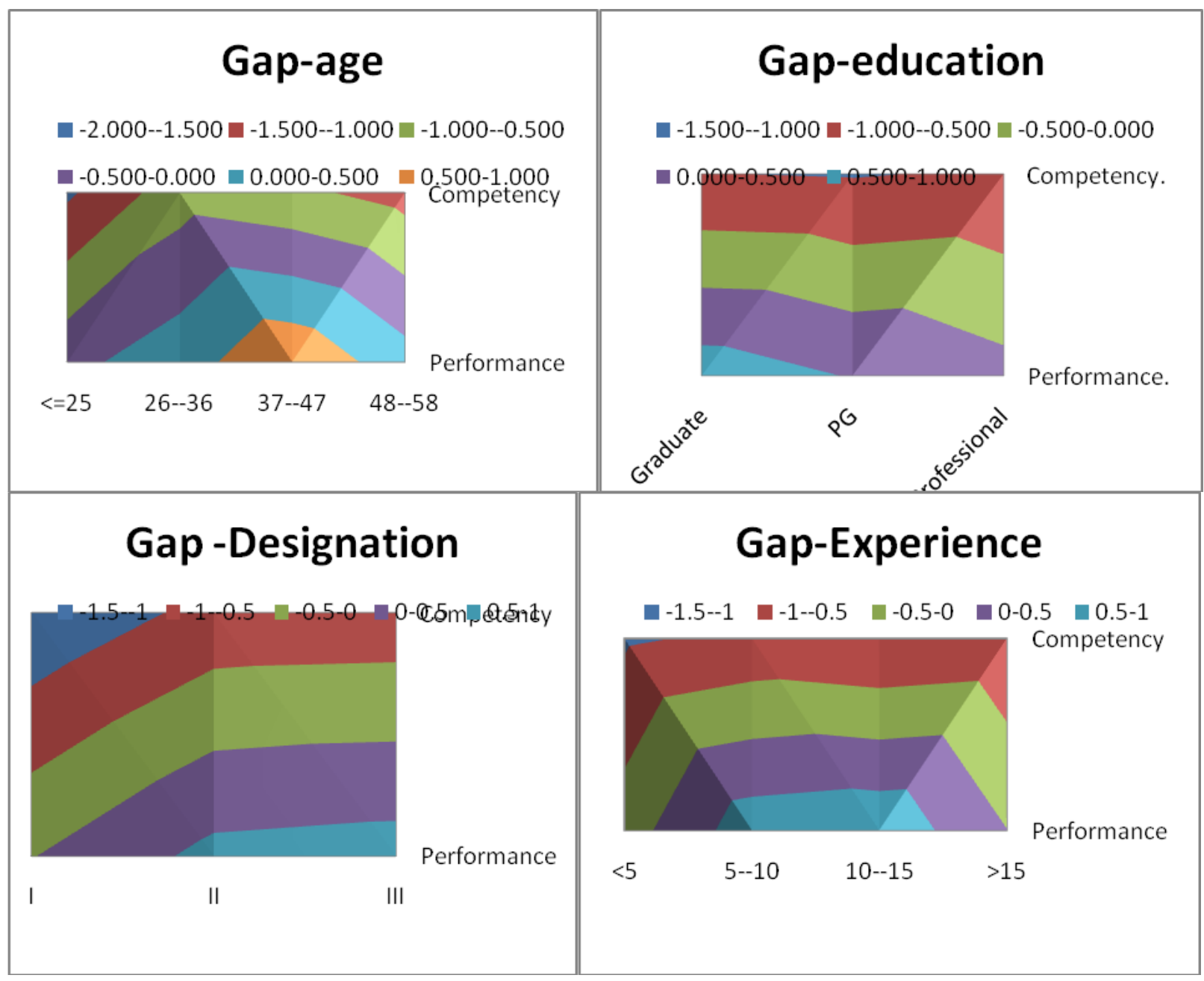

Linear Model

The linear model for Competency ( $\mathrm{N} \mathrm{Ex}$ ) is given below

\begin{tabular}{|l|c|c|c|c|c|}
\hline \multicolumn{7}{|c|}{ Model } & \multicolumn{5}{|c|}{ Coefficients } & \multirow{2}{*}{ Sig. } \\
\cline { 2 - 5 } & $\mathrm{B}$ & Std. Error & Beta & & \\
\hline (Constant) & .388 & .080 & & 4.846 & $.000^{*}$ \\
\hline PC & .132 & .013 & .241 & 10.289 & $.000^{*}$ \\
\hline LS & .186 & .013 & .346 & 14.233 & $.000^{*}$ \\
\hline RMS & .145 & .014 & .245 & 10.144 & $.000^{*}$ \\
\hline BC & .111 & .010 & .249 & 10.680 & $.000^{*}$ \\
\hline POS & .156 & .010 & .380 & 15.189 & $.000^{*}$ \\
\hline
\end{tabular}

The model is adequate as $\mathrm{R}$ Square is $91.3 \%$ with $\mathrm{SE}$ of estimate 0.07355.F forregression model in ANOVA $=409.492, \mathrm{p}$ value $=0.000$. From the standardised model for NEx competency, POS is contributively highfollowed by LS. Estimated minimum competency of an NEx employee is 1.118 and maximum is 4.038. The other linear model for Competency ( EX) and performance is given below 
Competency and Performance Gap between Executive and Non-Executive Employees of Banks in Kerala, India

\begin{tabular}{|l|c|c|c|c|c|c|c|c|c|}
\hline Ex Competency & Constant & PC & LS & RMS & BC & POS & Rsquare & SE & pvalue \\
\hline Coefficients & -.028 & .157 & .116 & .276 & .108 & .201 & 99.1 & 0.089 & \\
\hline Sig & .807 & $.000 *$ & $.000 *$ & $.000 *$ & $.000 *$ & $.000 *$ & & & $0.000 *$ \\
\hline
\end{tabular}

The minimum competency shown by Ex model is 0.83 and maximum competency is 4.462

\begin{tabular}{|l|c|c|c|c|c|c|c|c|}
\hline Ex Performnce & Constant & KS & CS & TS & IS & Rsquare & SE & pvalue \\
\hline Coefficients & .161 & .095 & .276 & .018 & .316 & 94.3 & 0.093 & \\
\hline Sig & .292 & $.000^{*}$ & $.000^{*}$ & .237 & $.000^{*}$ & & & $0.000^{*}$ \\
\hline
\end{tabular}

Minimum performance of Executive employees is 0.81 and maximum is 3.686.

Minimum performance of Executive employees is 2.073 and maximum is 4.841

\begin{tabular}{|l|l|l|l|l|l|l|l|l|}
\hline NEx Performnce & Constant & KS & CS & TS & IS & Rsquare & SE & pvalue \\
\hline Coefficients & 1.381 & .212 & .135 & .185 & .160 & 88.7 & 0.150 & \\
\hline Sig & $000 *$ & $.000 *$ & $.000^{*}$ & .237 & $.000 *$ & & & $0.000^{*}$ \\
\hline
\end{tabular}

\section{Binary Logistic Model}

Logistic regression model for Competency (NEx)

\begin{tabular}{|l|c|c|c|c|c|c|}
\hline \multicolumn{1}{|c|}{} & B & S.E. & Wald & df & Sig. & $\operatorname{Exp}(\mathrm{B})$ \\
\hline Age & .572 & .286 & 3.990 & 1 & .046 & 1.772 \\
\hline Education & -.463 & .227 & 4.160 & 1 & .041 & .629 \\
\hline Designation & -1.185 & .255 & 21.554 & 1 & .000 & .306 \\
\hline Experience & -.595 & .260 & 5.242 & 1 & .022 & .551 \\
\hline Constant & 3.156 & 1.073 & 8.660 & 1 & .003 & 23.485 \\
\hline
\end{tabular}

Among the demographic variables age, education, designation and experience are influencing variables and age is most influential one.Model identifies $63.5 \%$ cases as correct and satisfy Hosmer Lameshow test with Chi Square $=13.691$ with pvalue $=0.094>0.05$ and model is fit for the data. Competency of NEx is

\begin{tabular}{l} 
data. Competency of NEx is \\
\hline Model
\end{tabular}

From the model, probability for performance of executive staff of bank with minimum level of experience and age and designation is 0.608 and when they are at highest level of experience $(>47$ years and highest designation -III and highest experience $>15$ years) their performance probability is 0.9788 .

\section{Conclusion}

Competency based on 4 dimensions (PC, RMS, BC, POS) and performance based on 5 dimensions (KS, CS, LS, TS, IS)
$64.5 \%$ when graduates of age $<25$ with starting the job is found while it is $89.4 \%$ when age is $>48$, professional with highest designation and more than $15 y e a r s$ experience.

Other Logistic regression model for Competency (Ex) and Performance (NEx)

is evaluated on 200 non-executive and 100 executives of 4 banks. The responses by the employees are consistent and except performance of Ex all averages are behind middle expected value. Among the clerks, there is significant difference in competency and performance of sub groups of Education, Designation and experience. On competency it was significantly different for all age group and Ex and NEx. In all demographic groups there is significant difference in competency of Ex and NEx staff but in performance some sub groups are alike.

The Gap analysis shows that competency gap in executive and nonexecutive staff is significantly different in all except $\mathrm{BC}$ and in all except CS in performance gap. Demographic 
variable contributes gaps in performance and competency and it is varying between 0.5 to 1 unit positively in performance and negatively in competency. Two linear models each on performance and competency of executive and non-executive employees were found and they are adequate as minimum $\mathrm{R}$ Square is $88 \%$ for the models and $\mathrm{p}$ value for the models were all 0. Similarly four binary logistic regression models were determined and these models were adequate as Hosmer and Lameshow test give $\mathrm{p}$ value $>0.05$.

\section{REFERENCES}

[1] Bajpai, Naval; Srivastava, Deepak (2004), Sectorial comparison of factors influencing job satisfaction in Indian banking sector, Singapore Management Review, 26, 89-99.

[2] Branham,L.(2005), The 7 Hidden Reasons Employees Leave, New York: AMACOM,31-194.

[3] Barnett, Randy.E, Bernick Evan. (2018). The Letter and the Spirit: A Unified Theory of Originalism, Georgetown Law Faculty Publications and Other Works.

[4] Boyatzis. R.E. (1982). The Competent Manager: A Model for Effective Performance. John Wiley\&Sons,NewYork.

[5] Busco.C, Ribacconi.A, Scapens. R.(2006). Trust For Accounting And Accounting For Trust, AccountingResearch,Vol.17,11-41.

[6] Chen. M. F, Lien. G. Y. (2008). The Mediating Role of Job Stress in Predicting Retail Banking Employees' Turnover Intentions in Taiwan IEEE international conference on service operations andlogistics andinformatics.

[7] Cheng.Y, V.M. Canuto, A.M. Howard. (2003). Comments on an improved model for the turbulentPBL, Journal of Atmospheric Sciences, 60

[8] .Chan.J. K. L, Baum.T.(2007). Motivation Factors Of Ecotourists In Ecolodge Commodation: The Push And Pull Factors. Asia Pacific Journal Of Tourism Research,12 (4):349-364.

[9] Frimpong. K, Wilson.A. (2012). Measuring Service Orientation of Service Delivery Employees, The 12th International research conference in service management, La Londeles Maures, France..

[10] Griffith.J. (2003). Balanced Scorecard Use in New Zealand Government Departments and Grown Entities. Australian Journal of Public Administration, Vol. 62, N4, PP:70-79.

[11] Kadian.W.Wanyama,S.N.Mutsotso. (2010). Relationship between capacity building and employee productivity on performance of commercial banks in Kenya. Africa Journal of History and Culture,Vol.2.No.5,73-78.

[12] Kelley, S.W. (1990). Customer orientation of bank employees and culture. International Journal of Bank Marfating, 8(6), 25-29.

[13] Kim, Jennifer Lian Chan, Wei, Boon Quah. (2012). Start-up factors for small and medium-sized accommodation businesses in Sabah, Malaysia: push and pull factors. Asia Pacific Journal of Tourism Research, 17 (1). 49-62.

[14] Kueng. P. ( 2000). Process Performance Measurement System: A Tool To Support Process- Based Organizations. Total Quality Management, 11: 67-84.

[15] Key. E. (2003). Performance Evaluation Is The Most Important Case, "Dialogue", Idea, The Result, Human Resources, Istanbul, Turkey: Life Publishing. 33

[16] Ludeman. K. (2000). How To Conduct Self Directed 360, Training Dev, : 54: 44-47.

[17] Luft. J. (2004). Discussion Of Managers' Commitment To The Goals Contained In A Strategic Performance Measurement System. Contemporary Accounting Research, Vol.21, N4, PP: 959-964

[18] Mangaleswaran T, Srinivasan P T (2007) .A Comparative Study of Human Resource Management Practices in Sri Lakan and Indian Public Sector Banks. University of Jaffna.

[19] Modell .S. (2001). Performance Measurement And Institutional Processes: A Study Of Managerial Responses To Public Sector Reforms, Management Accounting Research, Vol.12, 437-464.

[20] Parker. C. (2000). Performance Measurement. Work Study, London,;49:2

[21] Sinclair.D., Zairi M.(1995). Effective Process Management through Performance Measurement, Part Applications of Total Quality-Based Performance Measurement, Business Process Re-Engineering \& Management Journal, 1: 75-88. 